\title{
ASSESSMENT OF MINING SOIL IMPROVEMENT AFTER CONSTRUCTION AND DEMOLITION WASTES AMENDMENT ADDITIONS EVALUATED BY MICROBIOLOGICAL ANALYSIS
}

\author{
F.J. MURCIA ${ }^{1,2}$ \\ M.J. GOMEZ $Z^{1,2}$ \\ A. PALOP ${ }^{2}$ \\ G. GARCIA ${ }^{1, *}$
}

\author{
${ }^{1}$ Soil Science and Agriculture Chemistry Unit \\ Agriculture Science and Technology Department \\ Technical University of Cartagena \\ Paseo de Alfonso XIII, 48, 30203-Cartagena, Spain \\ ${ }^{2}$ Food Technology Unit \\ Food Engineering and Agriculture Equipment Department \\ Technical University of Cartagena \\ Paseo de Alfonso XIII, 48, 30203-Cartagena, Spain
}

*to whom all correspondence should be addressed: e-mail: gregorio.garcia@upct.es

\begin{abstract}
Major environmental problems in metallic mining areas come from the hazard of metal pollution of surrounding areas. Therefore, an appropriated management of these soils is necessary for minimizing the associated risks. Some properties of mining soils, such as elevated metal concentrations, $\mathrm{pH}$ and shortage of essential nutrients make them a poor medium for organism growth. Therefore, in order to make a stabilization of these mining areas, it is necessary to solve previously some adverse physical and chemical soil factors mainly associated to toxic heavy metals and soil structure. Thus, some wastes such as carbonate, demolition wastes and sewage sludge, were added to soils to provide the needed conditions for improving soil conditions. The aim of this research was to assess the soil evolution after amendments addition in a research area placed in the Cartagena-La Unión Mining District, SE Spain. This assessment was carried out by means of microbial community evolution and variation as an indicator of soil changes. Mining soils showed, in general, low numbers of microorganisms, and significant increases in microbial populations were observed after soil treatment.
\end{abstract}

KEYWORDS: mining soil; amendment; demolition wastes; soil evolution; assessment; microbiology.

\section{INTRODUCTION}

Southeast Spain has supported an intense mining activity for more than two millenniums. Piles from ancient times, when less developed technologies were used, and especially more recent ones from large scale exploitations, are rich in content of various metals such as $\mathrm{Pb}$, As, $\mathrm{Cu}, \mathrm{Zn}, \mathrm{Hg}, \mathrm{Ni}$ and $\mathrm{Cd}$. These sediments have affected natural soils, causing their pollution by heavy metals. Therefore, these mining soils and sediments constitute a great environmental problem because they are exposed to water and wind erosion, which increase the risks of pollution of surrounding areas. Therefore, an appropriated management of these soils is necessary for minimizing the associated risks.

To minimize the environmental hazard, a soil remediation and restoration should be tackled in order to provide a soil stabilisation for the colonization of organisms. Using living organisms such as plants, for the stabilisation of soils, and microorganisms for immobilizing metallic toxic fractions in these soils, could be a good option to reduce risks (Cunningham et al., 1995; Greger, 1999). Phytostabilization is an in situ bioavailable metal reduction in contaminated soils by using tolerant plants that reduce the intrinsic hazard posed by metals (Greger, 1999; Khan et al., 2000). Studies concerning microorganism populations living in these areas have 
been proposed for immobilizing metallic toxic fractions in these soils (Bollag et al., 1993; Gao \& Tanji, 1995).

Anyhow, and prior to this colonization of organisms, some properties of mining soils such as acid pHs, high available metal concentrations, shortage of essential nutrients, etc. should be improved. Therefore, in order to make a stabilization of these mining areas, it was necessary to solve some adverse physical and chemical soils factors mainly associated to toxic heavy metals and soil structure. Thus, some wastes, such as carbonate, demolition wastes and sewage sludge, were added to soils to provide the needed conditions for improving soil conditions. The aim of this research was therefore to assess the soil evolution after amendments addition by means of evolution and variation of microbial communities.

\section{MATERIAL AND METHODS}

\subsection{Study area}

Research area is placed in the Cartagena-La Unión Mining District, SE Spain. This area has a typical termomediterranean climate with an average temperature of $18{ }^{\circ} \mathrm{C}$ throughout the year and a precipitation per year that ranges from $200 \mathrm{~mm}$ to $300 \mathrm{~mm}$.

\subsection{Soil samples analysis}

Soils from two different mining ponds of this area were analysed. Lirio pond had an almost neutral $\mathrm{pH}$ and Esperanza pond had an acid $\mathrm{pH}$ (2.5). Different doses of marble waste, sewage sludge and construction wastes were combined for soil amendments (Table 1). Previously, soils had been turned over to improve physical properties. Sewage sludge doses were calculated on the basis of nitrogen legislation (Nitrate Directive 91/676/EEC, 1991) and marble wastes doses were determined as the amount of carbonate required to raise $\mathrm{pH}$ up to 7 , and for that it was necessary to know the acid production through total sulphur estimation by peroxide oxidation (Lapakko, 2002; Sobek et al., 1978). Sewage sludge doses were estimated for a low, optimal and an excess of nitrogen in soils. Construction wastes doses were determined in order to improve physical structure of the mining soils. Organic, construction wastes and carbonate doses were the same used in previous studies in this area (Del Espino et al., 2005; Zanuzzi et al., 2004; 2005). Besides, blank plots (without amendment addition but mechanically dig up) and natural plots (natural soils without any treatment) were also analysed.

Table 1. Plot denomination and marble (carbonate), construction and demolition wastes and organic (sewage sludge) doses applied to two mining soils (Lirio pond and Esperanza pond). CD1: construction and demolition wastes dose 1, CD2: construction and demolition wastes dose 2, CD3: construction and demolition wastes dose 3, B: blank plot and N: natural mining

\begin{tabular}{lcccc}
\hline $\begin{array}{c}\text { Plot } \\
\text { denomination }\end{array}$ & $\begin{array}{c}\text { Dried marble } \\
\text { doses } \\
\left(\mathrm{g} \mathrm{m}^{-2}\right)\end{array}$ & $\begin{array}{c}\text { Sewage } \\
\text { sludge doses } \\
\left(\mathrm{g} \mathrm{m}^{-2}\right)\end{array}$ & $\begin{array}{c}\text { Construction waste } \\
\text { doses } \\
\left(\mathrm{g} \mathrm{m}^{-2}\right)\end{array}$ & $\begin{array}{c}\text { Mechanical } \\
\text { digging up }\end{array}$ \\
\hline Lirio - CD1 & 17500 & 350 & 1000 & Yes \\
Lirio - CD2 & 17500 & 350 & 2000 & Yes \\
Lirio - CD3 & 17500 & 350 & 3000 & Yes \\
Lirio - B & - & - & - & Yes \\
Lirio - N & - & - & - & Yes \\
Esperanza - CD1 & 52000 & 350 & 1000 & Yes \\
Esperanza - CD2 & 52000 & 350 & 2000 & Yes \\
Esperanza - CD3 & 52000 & 350 & 3000 & Yes \\
Esperanza - B & - & - & - & No \\
Esperanza - N & - & - & - & \\
\hline
\end{tabular}

Soil samples 0-15 depth were taken after one year of stabilization, air-dried (at room temperature) and crushed to pass through a $2 \mathrm{~mm}$ sieve, homogenized and stored in plastic bags prior to laboratory analysis. Samples were analysed in triplicate. Soil real $\mathrm{pH}$, in distilled water, and potential $\mathrm{pH}$, in $\mathrm{KCl}$, values were determined using glass electrodes in a 1:1 soil:water and soil: $\mathrm{KCl}$ paste (Peech, 1965) and total nitrogen was determined by TOC-V 
CSH Shimadzu with a coupled module TNM-1. Bioavailable metals ( $\mathrm{Zn}$ and $\mathrm{Pb}$ ) were extracted with DTPA solution (Lindsay and Novell, 1978) and measured by flame atomic absorption spectroscopy (UNICAM 969 AA spectrometer) and by inductively coupled plasma atomic mass spectroscopy (ICP-MS 4500 Agilent Technologies). All this data was already measured for previous works (Del Espino et al., 2005; Zanuzzi et al., 2005).

\subsection{Microbiological analysis}

Aliquots of the soil samples were analysed, in duplicate, following the recommendations of the American Public Health Association (APHA, 1998). After performing the appropriate dilutions, in buffered peptone water, the following microbial groups were studied for each sample:

- Bacteria, in Tryptone Soy Agar (TSA) at $31^{\circ} \mathrm{C}$ during $48-72 \mathrm{~h}$.

- Actinomycetes, in Actinomycetes-agar at $20^{\circ} \mathrm{C}$ during 5-7 days.

- Fungi, in Potato Dextrose Agar (PDA) + oxytetracicline at $20^{\circ} \mathrm{C}$ during 5-7 days.

- Sulfite reducing Clostridium, in Sulfite Polymyxin Sulfadiazine Agar (SPS) at $37^{\circ} \mathrm{C}$ during $24 \mathrm{~h}$ in anaerobiosis.

- Coliforms, in Brilliant Green Bile Lactose Broth at $37^{\circ} \mathrm{C}$ during $48 \mathrm{~h}$ by the Most Probable Number (MPN) method.

- Thiobacillus in Thiobacillus ferrooxidans medium $+\mathrm{FeSO}_{4}$ at $30^{\circ} \mathrm{C}$ during $48 \mathrm{~h}$ by the MPN method.

\section{RESULTS AND DISCUSSION}

\subsection{Effect of amendments on soil properties and characteristics}

Previous studies on this topic (Del Espino et al., 2005; Zanuzzi et al., 2004; 2005) revealed that there was an obvious effect of marble wastes, and perhaps sewage sludge, on $\mathrm{pH}$ and total $\mathrm{N}$ increment (Table 2). Thus, for all the treatments, except blank and natural plots without any amendment, all the $\mathrm{pH}$ values rose up to 7-8. Initial values before amendment applications were 6.7 and 2.5 for $\mathrm{pH}$ values in water of "Lirio pond" and "Esperanza pond" respectively, and 0.123 and $0\left(\mathrm{~g} \mathrm{~kg}^{-1}\right)$ for total nitrogen values of both ponds.

Table 2. $\mathrm{pH}$ in water and $\mathrm{KCl}$, total nitrogen and $\mathrm{Zn}$ and $\mathrm{Pb}$ bioavailability in blank and amended soils in Lirio and Esperanza ponds

\begin{tabular}{|c|c|c|c|c|c|}
\hline $\begin{array}{c}\text { Plot } \\
\text { denomination }\end{array}$ & $\mathrm{pH}\left(\mathrm{H}_{2} \mathrm{O}\right)$ & $\mathrm{pH}(\mathrm{KCl})$ & $\begin{array}{l}\mathrm{N} \text { total } \\
\left(\mathrm{g} \mathrm{kg}^{-1}\right)\end{array}$ & $\begin{array}{c}\mathrm{Zn} \\
\left(\mathrm{mg} \mathrm{kg}^{-1}\right)\end{array}$ & $\begin{array}{c}\mathrm{Pb} \\
\left(\mathrm{mg} \mathrm{kg}^{-1}\right)\end{array}$ \\
\hline Lirio - CD1 & 7.6 & 7.3 & 0.174 & 250 & 150 \\
\hline Lirio - CD2 & 7.5 & 7.3 & 0.179 & 255 & 165 \\
\hline Lirio - CD3 & 7.5 & 6.9 & 0.157 & 238 & 161 \\
\hline Lirio - B & 6.7 & 6.6 & 0.123 & 443 & 65 \\
\hline Lirio - $\mathrm{N}$ & 6.8 & 6.6 & 0.118 & 410 & 59 \\
\hline Esperanza - CD1 & 7.1 & 7.1 & 0.151 & 0.5 & 11 \\
\hline Esperanza - CD2 & 7.2 & 7.0 & 0.180 & 0.5 & 10 \\
\hline Esperanza - CD3 & 7.2 & 7.0 & 0.165 & 0 & 11 \\
\hline Esperanza-B & 2.5 & 2.2 & 0.000 & 4 & 12 \\
\hline Esperanza - N & 2.5 & 2.3 & 0.000 & 5 & 10 \\
\hline
\end{tabular}

Besides, available $\mathrm{Zn}$ decreased after amendment application but there is not a clear link among sewage sludge doses and $\mathrm{Pb}$ decrease (Table 2). Therefore, conditions for microbiology are significantly different between amendment soils, blank plots and natural mining soils without any treatment.

\subsection{Effect of amendments on soil microbiology}

The results show that the amendments added to the soil, at any of the concentrations tried, supported the growth of microbial populations at higher numbers than the blank samples and natural mining soils (without amendments and any mechanical treatment) in both ponds (Table 3), which would indicate improvements in soil properties and characteristics that 
persist even one year after the amendments were performed. Even coliforms were present, in low numbers, in some of the samples, but were not present neither in blank nor natural mining soils of both ponds.

It is remarkable that blank samples do not show significant differences in relation to natural mining soils for any of the microbial groups. It should be highlighted that the only difference between both plots are the aeration of soils in blank plots due to digging up. The only difference found between these two samples was related to clostridia, which were present in natural mining soils, but decreased significantly in blank samples, both for Lirio and Esperanza ponds. This difference could be caused by the aeration that would have a negative effect on these anaerobic microorganisms.

Table 3. Average log counts \pm standard deviation values for different microbial groups of soil samples taken at Lirio and Esperanza ponds after one year since the addition of the corresponding amendments

\begin{tabular}{lcccccc}
\hline $\begin{array}{c}\text { Plot } \\
\text { denomination }\end{array}$ & Bacteria & $\begin{array}{c}\text { Actinomy- } \\
\text { cetes }\end{array}$ & Fungi & Clostridia & $\begin{array}{c}\text { Thioba- } \\
\text { cili }\end{array}$ & Coliforms \\
\hline Lirio - CD1 & 4.38 & 4.36 & 2.98 & 2.80 & $<0.48$ & 0.60 \\
Lirio - CD2 & 4.25 & 5.09 & 3.62 & 2.20 & $<0.48$ & $<0.48$ \\
Lirio - CD3 & 5.54 & 5.34 & 4.31 & 1.81 & $<0.48$ & $<0.48$ \\
Lirio - B & $3.36 \pm 0.68$ & $2.93 \pm 0.86$ & $0.87 \pm 1.50$ & $1.12 \pm 1.04$ & $<0.48$ & $<0.48$ \\
Lirio - N & $3.12 \pm 0.83$ & $3.69 \pm 0.95$ & $2.68 \pm 0.51$ & $3.05 \pm 0.83$ & $<0.48$ & $<0.48$ \\
Esperanza - CD1 & 5.20 & 4.12 & 3.63 & 1.85 & $<0.48$ & 0.60 \\
Esperanza - CD2 & 5.11 & 3.30 & n.d. & 2.38 & $<0.48$ & $<0.48$ \\
Esperanza - CD3 & 4.93 & 3.19 & 2.18 & 1.81 & $<0.48$ & $<0.48$ \\
Esperanza - B & $2.55 \pm 2.49$ & $2.43 \pm 2.57$ & $3.01 \pm 0.64$ & $0.80 \pm 0.85$ & $<0.48$ & $<0.48$ \\
Esperanza - N & $2.49 \pm 0.11$ & $2.54 \pm 0.32$ & $2.70 \pm 0.89$ & $2.47 \pm 1.17$ & $<0.48$ & $<0.48$ \\
\hline
\end{tabular}

n.d.: not determined

Original values (blank samples and natural mining soils) for bacteria and actinomycetes counts were slightly lower for samples taken from Esperanza pond than from those of Lirio pond, and this difference could be caused by the $\mathrm{pH}$ value. Regarding this, after addition of amendments, $\mathrm{pH}$ was neutralised in both ponds and bacteria and actinomycetes counts increased to the same level.

It seems that characteristics of mining soils (blank and natural) are quite poor for supporting microbial growth, even when the $\mathrm{pH}$ of the soil is close to neutrality (Lirio pond). Therefore, the physical change made in soils by mechanical digging up, seems not to affect greatly to microbial populations.

Even mainly inorganic amendments, such as construction and demolition wastes, had a similar effect on microbial populations than organic amendments. Nevertheless, it should be highlighted that these amendments also had a small organic fraction that could help to support microbial growth. In this case it is not clear whether microorganisms have increased their number (related to blank samples) because of the organic matter or due to the improvement of soil structure.

Therefore, any of the organic amendments applied seemed to improve these characteristics and allowed microbial counts to increase significantly but without big differences between them, at least apparently. 


\section{CONCLUSIONS}

Addition of soil amendments to mining soils lead to changes of some soil properties and characteristics, such as $\mathrm{pH}$, total nitrogen and bioavailable metals. These changes represent an improvement of soil conditions that allow them to support growth, not only of microorganisms as shown in this research, but also of plants, leading to their stabilization.

Regarding microbial populations there are significant changes after soil treatment. Mining soils showed, in general, low numbers of microorganisms, but any of the amendments applied (at any of the concentrations) lead to a significant increase in the counts of the different microbial communities, what can be considered as a soil improvement caused by these amendments.

\section{ACKNOWLEDGMENTS}

This study has been performed in the framework of a project of the Spanish National Research Programme (ref. CGL2004-05963-C04-04), entitled "Integrated study of water quality in mining abandoned areas. Assessment on the surface and groundwater impacts and possible attenuation measures".

\section{REFERENCES}

APHA (1998) Standard Methods for the Examination of Water and Wastewater, 20th ed, American Public Health Association.

Bollag, J.M., Mertz, T.; Otjen, L. (1993) Role of microorganisms in soil bioremediation, Bioremediation through rhizosphere technology /ACS symposium series, 563, 2-10.

Cunningham, S.D., Berti W.R.; Huang, J.W. (1995) Phytoremediation of contaminated soils, Trends in biotechnology, 13 (9), 393-397.

Del Espino, C.; Zanuzzi, A.; Garcia, G. (2005) Addition of construction wastes, sewage sludge and carbonate for improving mining soil conditions prior to a phytostabilization programme. In: Proceedings of the Third European Bioremediation Conference, Crete, Greece.

Gao, S.; Tanji, K.K. (1995) Model for biomethylation and volatilization of selenium from agricultural evaporation ponds, Journal of environmental quality, 24(1), 191-197.

Greger, M. (1999) Screening of heavy metal tolerance and accumulation in higher plants for different phytoremediation purposes. In: Proceedings of the First Meeting of Working Group 2 of COST 837, Swiss F.I.T., Lausanne.

Khan, A.G., Kuek, C.; Chaudhry, T.M.; Khoo, C.S.; Hayes, W.J. (2000) Role of plants, mycorrhizae and phytochelators in heavy metal contaminated land remediation. Chemosphere, 41(1/2), 197-207.

Lindsay, W.L., Novell, W.A. (1978), Development of a DTPA soil test for Zn, Fe, Mn, and Cu, Soil Sci. Soc. Am. J., 42, 421-428.

Peech, M. (1965) Hidrogen-ion activity. In: C.A. Black (ed.) Methods for soil analysis. American Society of Agronomy. Madison, Wisconsin, USA. 2: 914-916

Zanuzzi, A.; Faz, A.; Garcia, G. (2004) Acidity production assessment to establish carbonate doses in mining soil reclamation using native plants. In: Fourth International Conference on Land Degradation, Cartagena, Spain, 12-17 September. Quaderna S.L., Spain, pp. 1-5.

Zanuzzi, A.; Faz, A.; Garcia, G. (2005) Effect of organic and carbonate amendments on heavy metal bioavailability. In: Proceedings of the Third European Bioremediation Conference, Crete, Greece. 